\title{
The European Neighbourhood Policy and the Democratic Values of the EU A Legal Analysis
}

This book offers a legal analysis of the European Neighbourhood Policy (the ENP) as it applies to developing relations with the EU's neighbours. It explores the legal aspects of this policy, including ENP competence matters, institutional arrangements and substantive policy issues, using international relations theory as the starting point in defining the EU's role as a political actor. The book focuses on the adequacy of the ENP legal framework for transposing the EU's democratic values and upholding its political image. In this connection, the book also features an analysis of EU democratic values as they are intended to be understood by its neighbours. The relevant legal framework of this policy and its implementation in the states of the South Caucasus (Georgia, Armenia and Azerbaijan) is evaluated, revealing the effects of the ENP in their democratic processes and the shortfalls of the ENP conditionality.

https://www.bloomsburyprofessional.com/uk/the-european-neighbourhood-policy-and-thedemocratic-values-of-the-eu-9781849462785/ 